\title{
A Comparative Analysis of National Strategies to Underpin Innovation Progress in Romania and Portugal
}

\author{
Corina-Cristiana NASTAC $\breve{A}^{1}$ \\ Ariana NĂSTĂSEANU ${ }^{2}$
}

Abstract

In the European Innovation Scoreboard (EIS) Romania ranks on the last place being considered a Modest Innovator which continues to allocate under 1\% of its GDP to research and development. In this respect, the present study aims to analyze Romania's innovation performance in comparison with Portugal's, a Strong Innovator and to propose a set of measures that could be implemented for improving Romania's position in the EIS. The research methodology consists of a comparative analysis concerning the innovation performance in Romania and Portugal using secondary data analysis gathered from the 2020 Edition of the European Innovation Scoreboard. The study revealed that Portugal and Romania are performing quite differently, with a common starting point as low performers in innovation in 2007. Portugal's performance in innovation is higher or similar to EU's average while for the majority of the analyzed indicators, Romania's position is below Portugal's and EU's average. Romania lags behind Portugal in a number of innovation indicators, especially regarding the Human resources and Attractive research systems indicators. Progress have been made in a very slow manner and even if Romania made efforts to increase its innovative capacity and adopted a national strategy for innovation, the situation did not improve very much in this area, remaining a Modest innovator, position in which Romania seems to be stuck for a decade.

Keywords: innovation, performance, European Innovation Scoreboard, Innovation Index, Romania, Portugal

JEL classification: I20, I23, I29

DOI: $10.24818 /$ RMCI.2021.1.4

\section{Introduction}

One of the most important tools for developing sustainable economies is innovation, a key factor used in all regional and national development strategies. Also, the European Union focuses on developing the innovation capacity of its Member States, and a relevant example is one of the targets introduced in the Europe 2020 Strategy- the allocation of $3 \%$ of the Gross Domestic Product (GDP) for Research and Development (European Commission, 2010). The Reflection paper: Towards a Sustainable Europe by 2030 (European Commission, 2019),

${ }^{1}$ Corina-Cristiana Nastacă, The Bucharest University of Economic Studies, corina.nastaca @ amp.ase.ro, 0754303579

2 Ariana Năstăseanu, The Bucharest University of Economic Studies, ariana.nastaseanu @ gmail.com, 0032-493-457.286

4 Review of International Comparative Management

Volume 22, Issue 1, March 2021 
outlines that education, science, technological development, research, and innovation are essential for a sustainable economy at the European level and even if progress has been made, the Member States are still far from achieving the 3\% of GDP allocation target in research and development.

The European Union designed Framework Programmes for Research and Innovation to boost competitiveness and investments as well as to develop sustainable economies. The problem is that in order to achieve a sustainable Europe until 2030, besides these framework programs and research and development finance mechanisms, a strategic approach of investments is needed, which should allow the introduction of innovative solutions, on the market. Developing and using innovative solutions presume capital investments with a high degree of risks and instruments like the European Fund have been designed to help at lowering the risks of these types of investments (European Commission, 2019). More than that, the European Innovation Council proposed measures for supporting companies, innovators, small and top researchers to expand abroad and achieve intellectual exchanges (European Commission, 2019).

The last report presenting The European Innovation Scoreboard (2020) showed that the European Union leads over China, Brazil, Russia, South Africa, and the United States regarding innovation indicators but it is behind states such as South Korea, Canada, Australia, and Japan. More than that, United Kingdom's withdrawal from the EU had a negative impact consisting of a small reduction of the EU's average innovation performance (European Commission, 2020).

Considering this situation and the new context caused by the Covid-19 pandemic, the Member States should continue their efforts for supporting innovation, by financing innovative technologies and companies to become market leaders with a positive impact on the EU's transition to sustainability (European Commission, 2020).

In comparison to the other Member States, Romania is considered a Modest Innovator which continues to allocate under 1\% of its GDP to research and development, ranking on the last place in the European Innovation Scoreboard. Even if Romania made efforts to increase its innovative capacity and adopted a national strategy for innovation, the situation did not improve very much in this area (Maier et al., 2017, Maier, 2018).

\section{Romania's and Portugal's innovation policies and performance}

The last report on the European Innovation Scoreboard from 2020 (European Commission, 2020), revealed that even with UK's withdrawal and the negative consequences of this situation, EU's innovation performance continued to increase on average by $8.9 \%$ since 2012 .

According to the Innovation Index, 24 Member States registered increases in their innovation performance. The most significant achievements could be observed in countries such as Lithuania, Malta, Latvia, Portugal, and Greece (European Commission, 2020). Sweden, Finland, Denmark, and the Netherlands

Review of International Comparative Management

Volume 22, Issue 1, March 2021 
remained innovation leaders (as compared to the previous year) and Luxembourg, in the past a Strong innovator, upgraded its position and became an Innovation leader. Major progress was registered by Portugal which evolved from the Moderate innovators to the Strong innovators group. Romania maintained its position, remaining in the Modest innovators group (European Commission, 2020).

Regarding Portugal's situation, it can be observed that the country is considered a Strong Innovator, ranking in the second position after Norway on the attractiveness of countries for innovators, with a score of 156.33 (European Commission, 2020). Several measures and indicators can explain Portugal's success in the European innovation ranking. GDP growth resumed in Portugal in 2014 and has been on an upward trend ever since, reaching 2.6\% in 2017, almost catching up with the EU15's annual growth rate and doubling between 2016 and 2017 (OECD, 2019). The Portuguese Agency for Competitiveness and Innovation and SME Investment (IAPMEI) launched several credit lines since 2008 to facilitate SMEs access to funding. In addition, the Agency will allocate, in the coming years, EUR 1.7 billion to SMEs as government-guaranteed credit lines and EUR 100 million in the form of mezzanine funding to fast-growth firms (The Portuguese Agency for SME and Innovation, 2020). Mezzanine financing is a hybrid of debt and equity financing that gives the lender the right to convert to an equity interest in the company in case of default, generally, after venture capital companies and other senior lenders are paid (Investopedia, 2020).

Portuguese business expenditure on R\&D (BERD) as a percentage of GDP fell from $0.75 \%$ to $0.59 \%$ of GDP between 2009 and 2014 (OECD, 2020). As of 2016, a set of reforms were designed covering four main dimensions addressing human resources, institutions, innovation systems and regional economic development. The main national innovation strategy is the Industrial Development Strategy for Growth and Employment (Estratégia de Fomento Industrial Para o Crescimento e o Emprego 2014-2020) developed in 2013 by the Ministry of Economy (Government of Portugal, 2013).

In 2014 the state support for research and development (R\&D) in Portugal was similar $(1,29)$ in terms of percentage of GDP with the allocation in Spain, Italy, and Luxemburg which situated between 1,24 and 1,34\% (Eurostat, 2014).

While comparing Portugal's business R\&D expenditure and innovation output performance, according to OECD data of 2020 these are below the OECD median, which has a double fold explanation: the country's specialization in lowand medium-low-technology industries and the small share of investment in R\&D by large companies compared with other European countries (OECD, 2020). A dedicated cluster policy has been promoted in some critical areas, such as marine technologies, and it is expected to be reactivated. Moreover, the internationalization of firms with innovative potential is of critical relevance for Portuguese enterprises (Sousa, Ferreira, Vaz, 2019). The area of entrepreneurship and $\mathrm{R} \& \mathrm{D}$, one of the strategic axes, is centered on the promotion of co-operation between science and industry. More recently, the Council of Ministers adopted the

$6 \quad$ Review of International Comparative Management

Volume 22, Issue 1, March 2021 
Technological and Business Innovation Strategy 2018-2030, partly based on the aforementioned Portugal knowledge strategy for European convergence (National Agency of Innovation, 2018).

The Portugal 2020 Partnership Agreement includes several major financing initiatives to stimulate business R\&D and innovation; foster cooperation among STI actors; and encourage the development of entrepreneurship and innovation in strategic sectors (European Commission, 2014).

Portugal has lean on EU's support offered through the Structural Funds as a source of funding for research and innovation-related activities and created dedicated management entities and co-ordination bodies to manage Funds implementation in these fields. An Inter-ministerial Commission for the coordination of the Partnership Agreement (CIC) has been created, headed by the minister in charge of the regional development, along with several functional networks, in areas such as research and innovation, regional economic development, smart specialization and science, technology and innovation support. (OECD 2019).

Since joining the European Union, Portugal has received significant financial support towards innovation and R\&D (Santos \& Simões, 2014) allowing the country to improve significantly its position in the European Commission Regional Innovation Scoreboard rank as it went from a low innovator to a moderate innovator over the last decade (Faria, Barbosa \& Bastos, 2020).

There is a need to support low and mid-tech businesses to develop Portugal's internal innovation capacity. The innovation capacity and output of Portuguese businesses have remained at a low level in international comparison, partly due to the dominance of SMEs and the weight of traditional sectors in the economy. Although more could be done to promote engagement with industry among academic institutions and staff, at present, there are only a limited number of companies with sufficient 'absorption capacity' to collaborate effectively with academic partners. It is therefore important to support more low and mid-tech businesses that do not yet innovate significantly and serve mainly regional markets to develop their internal innovation capacity and exploit the opportunities offered by cooperation with the academic sector. This could be done through 'regional innovation platforms' that provide domestic SMEs easy access to resources such as information, expertise, and equipment that allow them to upgrade their innovation capabilities (OECD, 2019).

Regarding Romania's position in the European Innovation Scoreboard, it can be observed that the country ranks the last in The Innovation Index, being considered a Modest Innovator.

From 2007 (when Romania joined the UE) the innovation performance mostly increased until 2011 when it started to decline (European Innovation Scoreboard, 2015). The development of Romania's relative performance to the EU has closely followed the development of the innovation index. The weakest relative performance in terms of dimensions in 2015 was registered for Linkages and entrepreneurship while in terms of indicators the worst relative performance was 
observed for PCT patent applications and PCT patent applications in societal challenges. Romania performed similar to the EU average for a number of indicators, in particular New doctorate graduates, Exports in knowledge-intensive services and Youth with upper secondary level education (European Innovation Scoreboard, 2015). In the present, the country's innovation performance remains poor, ranking last among Member States (European Commission, 2020). Investments in employee training and ICT solutions are lower than the EU average (European Commission, 2020). R\&D investment is very low, with an R\&D intensity of $0.51 \%$ of its GDP in 2018, well below the 2020 national target of $2 \%$ and the EU average of $2.12 \%$. Public R\&D investment was $0.2 \%$ of its GDP in 2018. Private expenditure on R\&D was only $0.30 \%$ of GDP, below the EU's average of $1.41 \%$ (European Commission, 2020).

The state support for research and development (R\&D) in Romania from 2000 until 2017 remained steadily around $0.5 \%$ of the GDP. The situation since then hasn't improved and in 2020 Romania allocated to this area only $0.51 \%$ of GDP.

In the last European Innovation Scoreboard (European Commission, 2020), the strongest innovation dimensions were Innovation-friendly environment and Sales impacts. Romania's performance was similar to the EU's average on the Broadband penetration and Medium and high-tech product exports indicators. The weakest innovation dimensions were Innovators, Firm investments, and Human resources. Also, the lowest scores were registered at Lifelong learning, SMEs with product or process innovations, SMEs with marketing or organizational innovations, and SMEs innovating in-house indicators. For all four mentioned indicators Romania performed the worst of all countries (European Commission, 2020).

The RD\&I system in Romania consists of 263 public R\&D organizations (56 public universities, 46 national $R \& D$ institutes, 65 research institutes and centers of the Romanian Academy, and another 96 public research institutes and centers), and about 600 private companies. The network for technology transfer and innovation (ReNITT) has around 50 specific organizations (technology transfer centers, technology information centers, technology and business incubators). The number of $R \& D$ personnel in the public sector was approx. 31.500 in 2018. The percentage of researchers per 1000 civil employed persons was 2.02 (OECD, 2018).

To tackle the challenges, a tax exemption on salary incomes for the personnel involved in CD activities came into force since 2016. The exemption is granted for all persons included in the team of an RD\&I project within the limits for personnel costs.

In the last academic years, the distribution of students by specialization shows higher weights in certain areas. In 2016-2017, 23.7\% of undergraduate students were enrolled in business, administration and law; $21.1 \%$ in engineering, processing and construction; and $16 \%$ in the health and social assistance group. The lowest numbers are recorded in the following fields: education sciences $(3.1 \%)$, services $(3.7 \%)$, and natural sciences, mathematics and statistics $(4.1 \%)$.

$8 \quad$ Review of International Comparative Management

Volume 22, Issue 1, March 2021 
The last group is critical for R\&D capacity and therefore for the development of technology- and knowledge-intensive sectors.

Romanian Government approved the Third National Research and Development Innovation Plan for 2015-2020 period (Romanian Government, 2015), which is one of the main instruments for the implementation of the National Strategy in this field, comprising five programs of major importance (Romanian Government, 2014):

1. Development of a National Research and Development System (research projects to stimulate young researchers and independent teams, etc.);

2. Increasing the competitiveness of the Romanian economy, providing support for the development of models and solutions for products;

3. European and international cooperation program;

4. Fundamental and frontier research designed to maintain and develop niche areas;

5. Research in areas of strategic interest, support program led by institutions with a scientific role for the development of research institutions.

The main objectives tap on the transformation of the National RDI system into a functional, efficient, performance-related one, supported by a critical mass of researchers in the system and developing new generations of international competitive researchers. The Plan foresees to increase effective public funding by pooling resources in areas of economic relevance demonstrating research potential (especially intelligent specialization areas) and stimulating private spending for research, development and innovation through public co-financing to reach, by 2020, a level of $1 \%$ of GDP.

On 14 May 2020 the Romanian Government approved the memorandum on the use of the Policy Support Mechanism (PSM) of Horizon 2020, for the evaluation of national policies in the field of research and innovation, governance and institutional architecture, with a view to better integration into the European Research Area. "Policy Support Facility" (PSF), represents the mechanism supporting the reform of national RDI policies, which provides independent support to national public authorities with RDI assignments from experts recognized by the European Commission and is 100\% funded by Horizon 2020 . With this memorandum, the Government has assumed its peer review through the PSM instrument, which will run for a maximum of one year, the costs being fully covered by the European Commission through Horizon 2020. Following the dialogue with the European Commission, the Ministry of Education and Research assumed implementing the reforms of the PSM, by creating an independent structure with a temporary status organized at the level of the directorate (Romanian Government, 2020).

\section{Research Methodology}

The purpose of this study is to analyze Romania's innovation performance in comparison with Portugal's, considered to be a Strong Innovator. A set of indicators were collected and analyzed in order to reveal the major problems and weaknesses in the Romanian research, development, and innovation area. Also, the 
research proposes a set of measures that could be implemented for improving Romania's position in the European Innovation Scoreboard.

The main objectives of the study are:

1. To investigate Romania's position in the European Innovation Scoreboard 2020 and its progress compared with European Union's average.

2. To compare Romania's innovation performance with Portugal's, a Strong Innovator.

3. To propose measures to improve Romania's innovative performance based on the lessons learned from the other European Member States.

The research methodology consists of a comparative analysis concerning the innovation performance in Romania and Portugal using secondary data analysis. The data were gathered from the European Innovation Scoreboard - 2020 Edition, for the two selected countries.

The European Innovation Scoreboard (EIS) presents the innovation performance of the European Member States, other European countries, regional neighbors, and other selected countries (such as US, Japan, or China), in a comparative manner, revealing which are the strengths and weaknesses of the national innovation systems. According to their scores and position in the EIS, countries can identify their weak spots regarding the innovation systems and the main areas they need to orientate their actions and innovation policies (European Commission, 2020). The EIS divides the Member States, based on their average performance scores into four performance groups: Innovative Leaders, Strong Innovators, Moderate Innovators, and Modest Innovators. Their innovative performance is measured through ten innovation dimensions, grouped into four types of activities. The first activity, namely Framework conditions are based on three dimensions- Human resources, Attractive research systems, and an Innovation-friendly environment. The second activity- Investments, covers two dimensions: Finance and support and Firm investments. The third activity is Innovation activities and comprises three dimensions- Innovators, Linkages, and Intellectual assets and the last activity, namely Impacts, is formed by two dimensions: Employment impacts and Sales impacts. All ten dimensions are measured using 27 indicators.

All the collected data is presented comparatively, by dimensions and the indicators which measure them, in order to reveal the differences in innovation performance between Romania and Portugal and their position compared with the European Union's average. The used data is the most recent one, from 2019, analyzed in the European Innovation Scoreboard- 2020 Edition. The reason for choosing these particular countries is that Portugal is one of the countries which registered a major performance increase, despite the circumstances created by the Covid-19 pandemic, evolving from the Moderate Innovators category in 2019 to Strong Innovators in 2020. Romania remains a Modest Innovator, being one of the two countries where the innovation performance decreased the most, along with Slovenia. In these circumstances, the comparison between two countries situated at opposite poles, is important, to reveal which are Romania's weakness and the areas

10 Review of International Comparative Management

Volume 22, Issue 1, March 2021 
where it should focus its policies and actions to improve its innovation performance.

\section{The main findings of the study regarding Romania's and Portugal's innovation performance}

In this chapter, the results of the comparative analysis regarding Romania's and Portugal's innovation performance will be presented. The collected data were compared by the dimensions and indicators used in the European Innovation Scoreboard (2020). In addition, all the indicators were compared with EU27's average, to outline the differences and similarities between the selected countries' performance and the innovation performance at the European level.

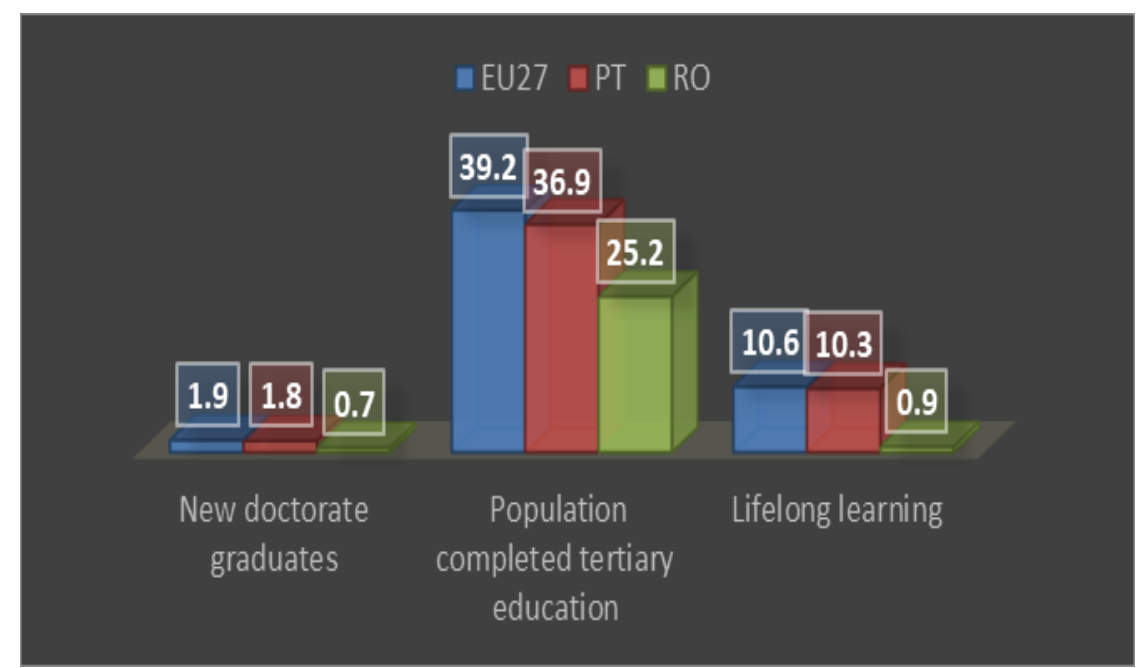

Figure 1: Comparison between Romania and Portugal regarding the Human resources dimension

Source: Authors, adapted by the European Innovation Scoreboard (2020)

Figure 1 presents the comparison between Human resources dimension indicators: New doctorate graduates per 1000 population aged 25-34, Percentage population aged 25-34 having completed tertiary education, and Percentage population aged 25-64 involved in lifelong learning. It can be observed that in 2019, Romania had only 0.7 doctorate graduates per 1000 population, compared with Portugal which was very close to the EU27 average (1.8 vs. 1.9). Regarding the population aged 25-34 that completed tertiary education, there were major differences between Romania and Portugal. Portugal was close to the EU's average with $36.9 \%$ graduates quite comparable with $39.2 \%$ at the European level. In Romania, the percentage was only $25.2 \%$. The situation improved in the case of the lifelong learning indicator, where Romania was close to Portugal and the EU's average $(0.9 \%$ vs. $10.3 \%$ and $10.6 \%$ in the EU).

Review of International Comparative Management

Volume 22, Issue 1, March 2021 


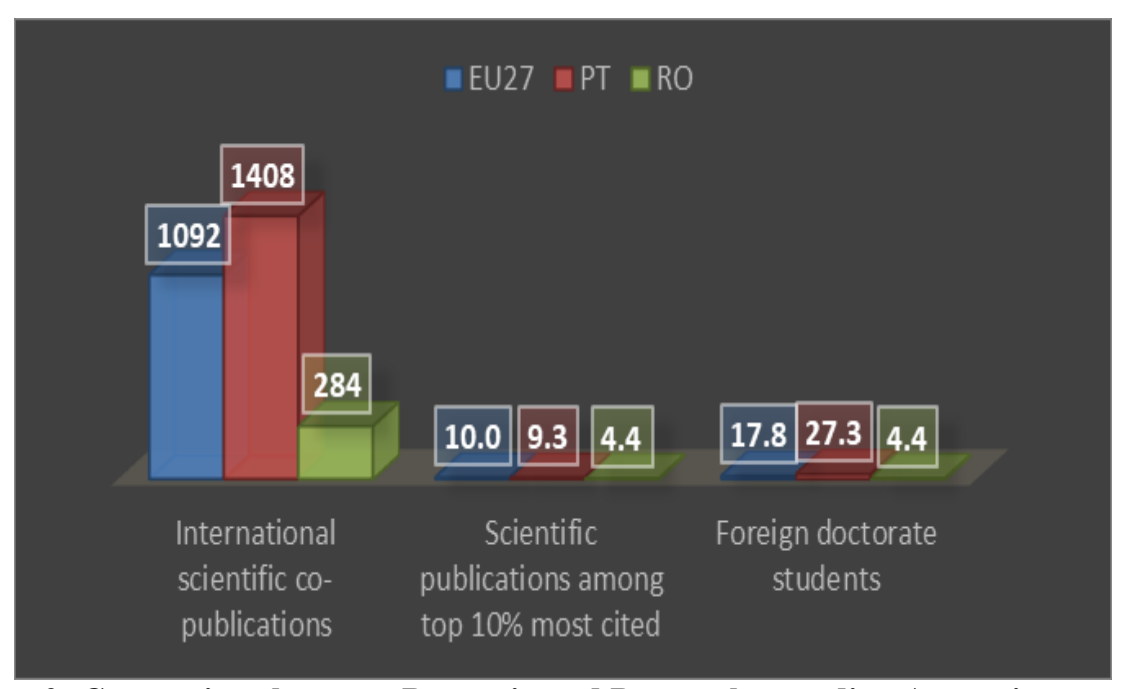

Figure 2: Comparison between Romania and Portugal regarding Attractive research systems dimension

Source: Authors, adapted by the European Innovation Scoreboard (2020)

Figure 2 outlines Romania's weak performances regarding all the indicators that comprise the Attractive research systems dimension. It can be observed that in 2019 there were only 284 international scientific co-publications per million population in Romania far below Portugal (1408) which rated above the EU's average (1092). Regarding the scientific publications among the top $10 \%$ most cited publications worldwide as \% of total scientific publications of the country, Portugal was close to EU's average (9.3\% vs. $10 \%)$ while Romania registered only $4.4 \%$. As far as the foreign doctorate students as a $\%$ of all doctorate students indicator is concerned, Portugal was above EU's level $(27.3 \%$ vs. $17.8 \%$ ) while Romania is far below (only $4.4 \%$ ).

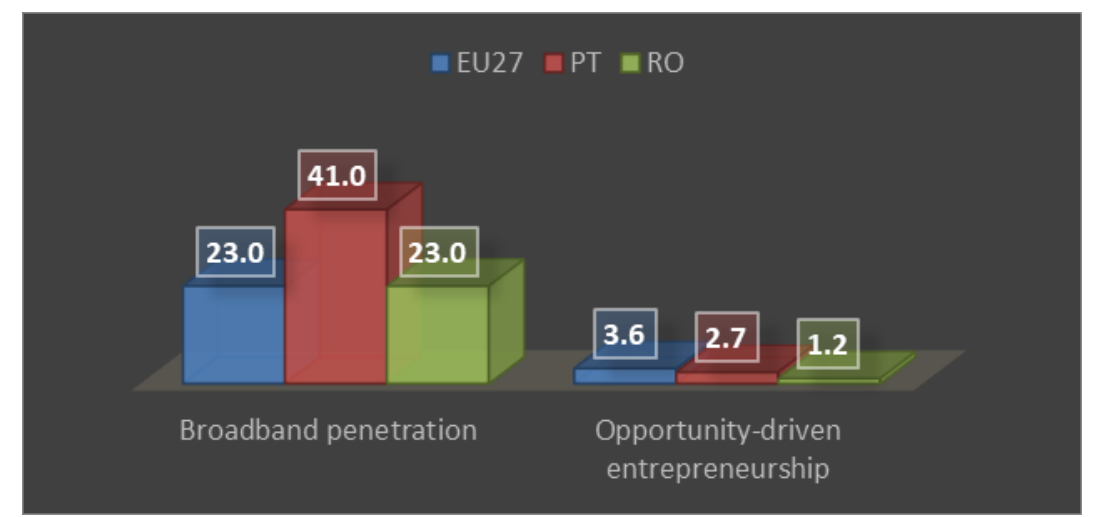

Figure 3: Comparison between Romania and Portugal regarding innovation-friendly environment dimension

Source: Authors, adapted by the European Innovation Scoreboard (2020) 
Figure 3 presents the comparison between innovation-friendly environment indicators, such as Broadband penetration (subscriptions per 100 inhabitants) and Opportunity-driven entrepreneurship (Motivational index). Regarding broadband penetration, Romania's situation was similar to the EU's average $(23 \%)$ and below Portugal's (41\%). As for Opportunity-driven entrepreneurship, the motivational index was 1.2 for Romania, while Portugal was closer to the EU's average (2.7 vs. 1.2). At this dimension, Romania had the best performance from all the analyzed dimensions.

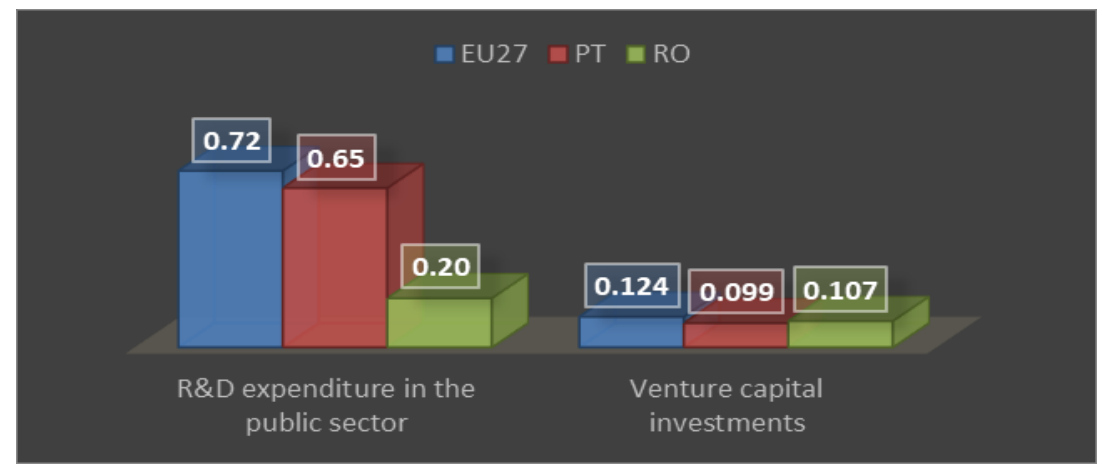

Figure 4: Comparison between Romania and Portugal regarding Finance and support dimension

Source: Authors, adapted by the European Innovation Scoreboard (2020)

Regarding Finance and support indicators presented in figure 4, it can be outlined the low level of R\&D expenditure in the public sector (\% of GDP) in Romania's case $(0.2 \%)$ compared with Portugal's $(0.65 \%)$ that was closer to EU average $(0.72 \%)$. Regarding Venture capital (\% of GDP), Romania's allocation was higher than Portugal's (0.107\% vs. $0.099 \%)$ and closer to the EU's average $(0.124 \%)$.

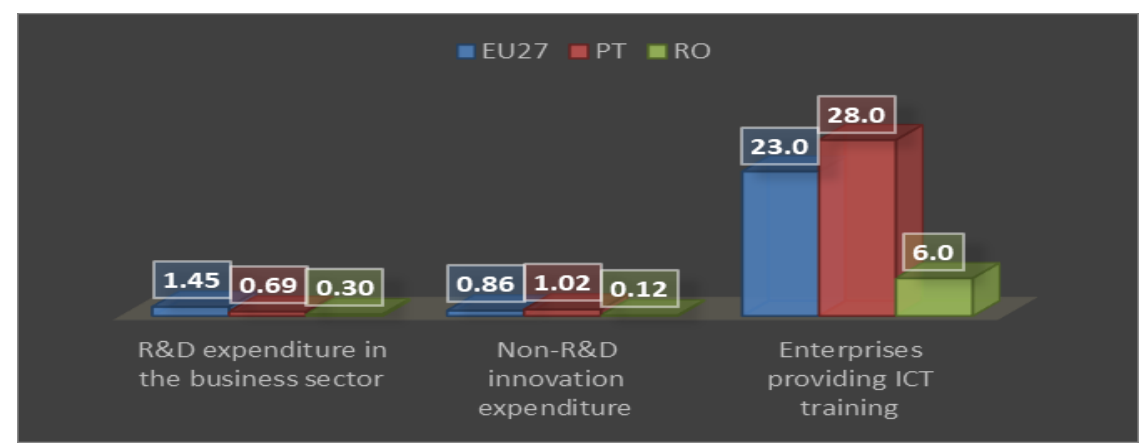

Figure 5: Comparison between Romania and Portugal regarding Firm investments dimension

Source: Authors, adapted by the European Innovation Scoreboard (2020) 
Figure 5 shows major differences related to Romania's performance on Firm investments indicators. It can be observed that the R\&D expenditure in the business sector (\% of GDP) was only $0.30 \%$ compared with Portugal $(0.69 \%$ ). Both countries allocated less than the EU's average (1.45\%). Concerning the nonR\&D innovation expenditures (\% of turnover), Portugal's situation was above the EU's average ( 1.02 vs. 0.86 ) while Romania allocated expenses of only $0.12 \%$. Regarding the enterprises providing training to develop or upgrade the ICT skills of their personnel, Portugal was above the European average (28 vs. 23) and Romania situated far below (6).

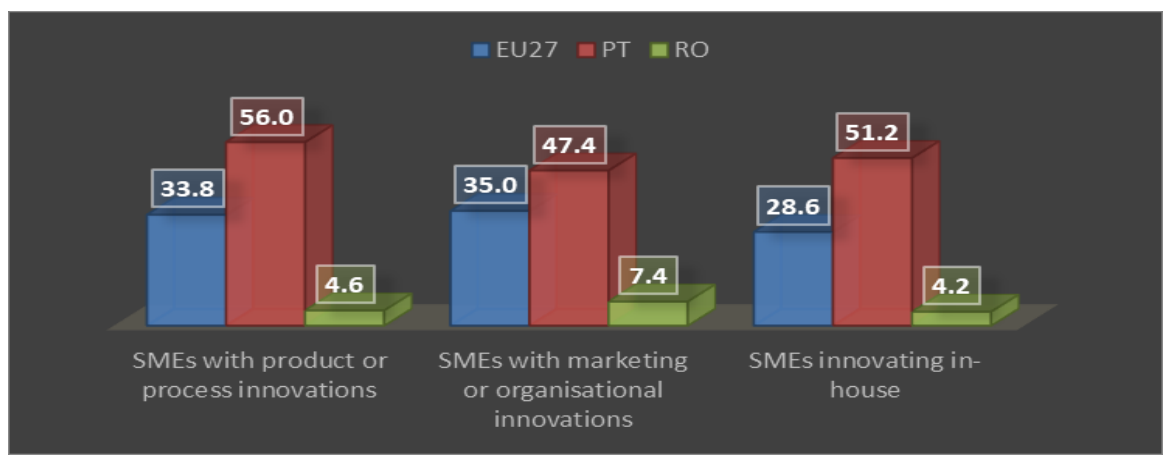

Figure 6: Comparison between Romania and Portugal regarding Innovators dimension

Source: Authors, adapted by the European Innovation Scoreboard (2020)

Regarding the Innovators dimension, it can be observed that Romania's performance on the indicators comprising this dimension was very weak. Portugal's performance was above the European average at all three indicators and Romania's percentage of SMEs introducing product or process innovations, SMEs which are introducing marketing or organizational innovations, and SMEs innovating in-house was extremely low $(4.6 \%, 7.4 \%$, and $4.2 \%)$.

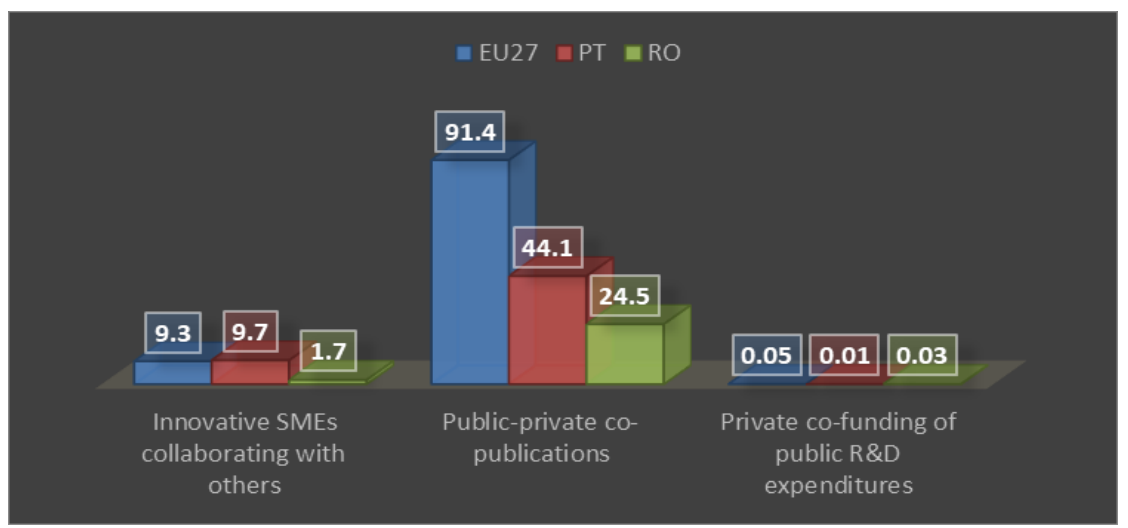

Figure 7: Comparison between Romania and Portugal regarding Linkages dimension Source: Authors, adapted by the European Innovation Scoreboard (2020) 
Regarding the Linkages indicators presented in figure 7, Romania's situation was favorable only in the case of Private co-funding of public R\&D expenditures, with an allocation from GDP higher as in Portugal's case $(0.03 \%$ vs. $0.01 \%$ ) but under the European average $(0.05 \%)$. Observing the number of publicprivate co-publications per million population, both countries were far behind the European average- 24.5 publications in Romania, 44.1 in Portugal, and 91.4 at the EU's level. The percentage of Innovative SMEs collaborating with others was the lowest in Romania's case (1.7\%) and higher than the European average in Portugal's case ( $9.3 \%$ vs. $9.7 \%)$.

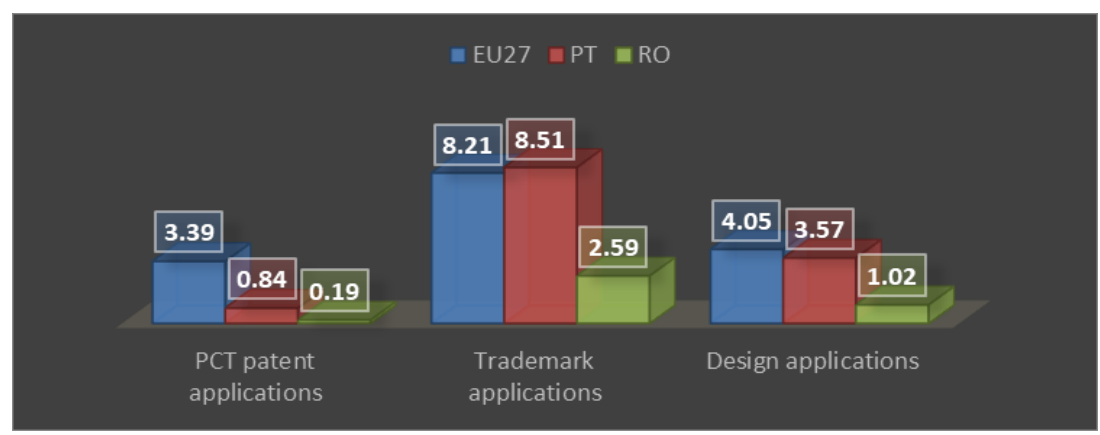

Figure 8: Comparison between Romania and Portugal regarding Intellectual assets dimension

Source: Authors, adapted by the European Innovation Scoreboard (2020)

The intellectual assets indicators also showed a weak performance of Romania. The PCT patent applications per billion GDP (in PPS) were at a low level in both countries, compared with the European average. Portugal's performance was better in the case of the trademark applications per billion GDP (in PPS) and higher than the EU's average (8.51 vs. 8.21). In Romania, there were only 2.59 trademark applications in 2019. Regarding the design applications per billion GDP (in PPS), the situation was similar in Portugal's case and at the EU's level (3.57 vs. 4.05) while Romania registered only 1.02 applications.

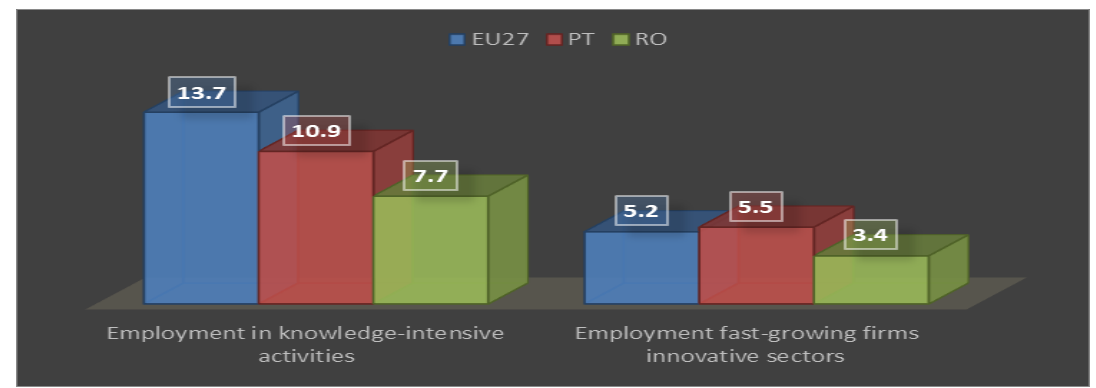

Figure 9: Comparison between Romania and Portugal regarding Employment impacts dimension

Source: Authors, adapted by the European Innovation Scoreboard (2020) 
The Employment impacts indicators in figure 9 reveal a better performance of Romania as in the other indicators' case. The percentage of employment in knowledge-intensive activities is almost a half from the European average and with almost 3\% lower as in Portugal's case. Regarding Employment in fast-growing enterprises, Portugal was situated over the European average (5.5\% vs. 5.2\%) and Romania had a $3.4 \%$ of employees from the total employment, working in this type of enterprise.

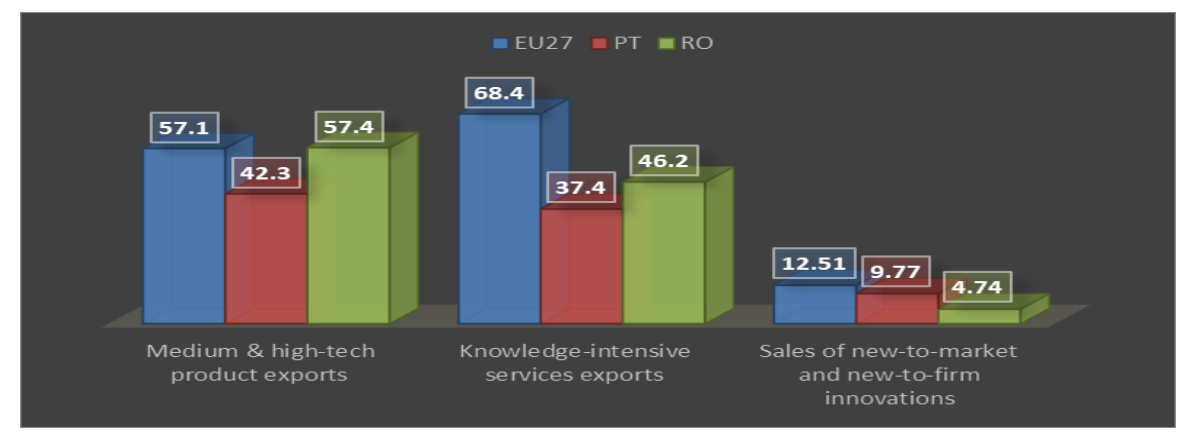

Figure 10: Comparison between Romania and Portugal regarding Sales impacts dimension

Source: Authors, adapted by the European Innovation Scoreboard (2020)

On the Sales impacts, dimension Romania performed well compared with other dimensions and indicators. The Exports of medium and high technology products as a share of total product exports was higher than the European average $(57.4 \%$ vs. $57.1 \%)$ and Portugal's case $(42.3 \%)$. Regarding the Knowledgeintensive services exports as \% of total services exports, Romania performed better than Portugal (46.2\% vs. 37.4\%) but situating below the European level (68.4\%). Romania had the weakest performance on the Sales of new-to-market and new-tofirm innovations as \% of turnover indicator, situating under the European level ( $4.74 \%$ vs. $12.51 \%)$. It can be observed that Portugal's performance was close to the EU's average $(9.77 \%)$.

\section{Main challenges and possible solutions, especially in the pandemic situation}

A number of 10 dimensions have been analyzed in the previous chapter covering various dimensions of the innovation eco-system in the two countries. The improvements made by Portugal since 2018 (when it was still a Moderate innovator, but steadily improving towards the position as Strong innovator) could open some path to explore possible lessons learnt.

As long as some of the main drivers of stimulating innovation through public expenditure remain low, the results will lag behind expectations. The scarcity of the resources combined with lack of ecosystem aiming to spur

16 Review of International Comparative Management

Volume 22, Issue 1, March 2021 
innovation will continue to negatively impact the gap between the Modest innovator position in which Romania seems to be stuck for a decade.

Taking into consideration that overall, the economic performance depends on innovation in general, and especially digital and new frontier technologies, the productivity boost they could provide at a time when changing demographics are acting as a drag on growth.

One of the first recovery measures that should be considered to bridge the gap of the innovation performance is ensuring sufficient public and private investment for research and innovation. The signal sent by the public sector should be vigorous, reaching at least $1 \%$ of the GDP that could trigger an adequate response from banks, venture capital companies, and the private investment sector. Equity finance as a key driver for innovation remains underdeveloped, with 90 percent of the European Union's venture capital funding concentrated in only eight member states (Bughin et al., 2019).

A set of measures stimulating the next wave of frontier technologies, including artificial intelligence, Internet of Things, block-chain, high-power computing, must be stimulated in view of the potential to deliver the breakthrough in productivity. The Romanian Academy initiated a "Manifesto for adaptation to the digital age" i.e. scientific debates on information and communication technologies (ICT) and artificial intelligence (AI), focusing on their effect on society as a whole, as well as on the role of robotics in Romanian society.

A third pillar of proposed measures relates to the labor-force and the skills required by the fast-growing enterprises. The number-one obstacle to investing more in $\mathrm{R} \& \mathrm{D}$ and digitization is represented by the lack of skills (European Investment Bank, 2018). Romania as part of the EU has to put in place a plan to try to prevent the brain-drain phenomenon, fostering international cooperation with well-known universities and promoting fiscal incentives, which can be effective in raising $R \& D$, especially when firms face financial constraints. Tax relief for private $R \& D$ is often found to provide a stronger stimulus to business $R \& D$ than direct government support (OECD, 2007). This could include encouraging the return of high skilled workers who live abroad.

The economic impact of the pandemic is already tangible and will unfold over a longer time frame. Comparisons with the global financial crisis may go some way to convey the seriousness of the pandemic, but that crisis will undoubtedly pale in comparison.

\section{Conclusions and lessons learned}

Analyzing the main drivers of the European Innovation Scoreboard 2020, Portugal and Romania are performing quite differently, with a common starting point as low performers in innovation in 2007. However, the leap made by Portugal in 2019-2020 is impressive if one compares the situation of three decades ago. Portugal was recognized by its 'lack of co-operation culture, the individualistic behavior of the firms and their human, technological and financial chronic 
handicaps, the predominance of non-qualified labor pools, the absence of sciencebased industries, the lack of investments in R\&D and other intangible factors, the low density and quality of the innovation infrastructures and an erratic innovation policy' (Santos \& Simões, 2014,). With a large number of research institutions, some of them with a good scientific reputation and staffed with highly qualified researchers, nevertheless, the processes of technology transfer to industry steadily improved recently due to policies oriented towards the creation of transfer mechanisms, the pressure on public institutions to self-finance their activities and the increased technological awareness of industry.

Romania however lags behind Portugal in a number of innovation indicators, but especially regarding the Human resources dimension indicators. There are major differences between Romania and Portugal regarding the population aged 25-34 that completed tertiary education, with Portugal is close to the EU's average with $36.9 \%$ graduates quite comparable with $39.2 \%$ at the European level whilst in Romania the percentage is only $25.2 \%$. Effort should be made by the public responsible authorities to fill the gap between the EU average percentages. To summarize, in Romania the public system is too fragmented with respect to the available funding, struggling with a low administrative capacity. There are too many strategies suffering from overlaps and discrepancies between design and implementation, significant degree of fragmentation of the public system, lack of coordination and communication and insufficient and unpredictable financing. The financing agencies such as the Executive Unit for Financing Higher Education, Research, Development and Innovation (UEFISCDI), Romanian Space Agency (ROSA) and Institute for Atomic Physics (IFA) are managing the implementation of the National RD\&I Plan, however they alone cannot support the economy to transition towards a knowledge based one.

\section{REFERENCES}

1. Bughin, J., Windhagen E., Smit, S., Mischke, J., Sjatil, P. E., Gürich, B., 2019, Innovation in Europe. Changing the game to regain a competitive edge, McKinsey Global Institute.

2. European Commission, 2010, EUROPA 2020, O strategie europeană pentru o creștere inteligentă, ecologică şi favorabilă incluziunii, [[Online]], Available at: https://eur-lex.europa.eu/legal-content/RO/TXT/PDF/?uri=CELEX:52010DC2020 $\&$ from=en. [Accessed 20 January 2021].

3. European Commission, 2014, Acordo de parceria 2014-2020, [Online], Available at: http://www.qren.pt/np4/np4/?newsId=4209\&fileName=ACORDO_DE_PARCERIA. pdf. [Accessed 20 February 2021].

4. European Commission, 2019, REFLECTION PAPER TOWARDS A SUSTAINABLE EUROPE BY 2030, [Online], Available at: https://ec.europa.eu/info/sites/info/ files/rp_sustainable_europe_30-01_en_web.pdf. [Accessed 27 January 2021].

5. European Commission, 2020, European Innovation Scoreboard 2020, [Online], Available at: https://ec.europa.eu/docsroom/documents/42981. [Accessed 29 January 2021].

18 Review of International Comparative Management

Volume 22, Issue 1, March 2021 
6. European Commission, 2015, European Innovation Scoreboard 2015, [Online], Available at: https://op.europa.eu/en/publication-detail/-/publication/b00c3803-a94011e5-b528-01aa75ed71a1. [Accessed 29 January 2021].

7. European Investment Bank, 2018, Investment report 2018/2019: Retooling Europe's economy, [Online], Available at: https://www.eib.org/attachments/efs /economic_investment_report_2018_key_findings_en.pdf. [Accessed 29 January 2021].

8. Eurostat, 2014, Science, Technology and Innovation, [Online], Available at: https://ec.europa.eu/eurostat/web/science-technology-innovation. [Accessed 27 January 2021].

9. Faria, A.P, Barbosa, N. \& Bastos, J., 2020 Portuguese regional innovation systems efficiency in the European Union context, European Planning Studies, 28(8), pp. 1599-1618, DOI: 10.1080/09654313.2019.1680611.

10. Government of Portugal, 2013, Estratégia de Fomento Industrial Para o Crescimento e o Emprego 2014-2020, [Online], Available at: https://www.dn.pt/DNMultimedia /DOCS+PDFS/ECEFI\%202013.pdf. [Accessed 27 February 2021].

11. Investopedia, 2020, Mezzanine Financing, [Online], Available at: https://www.investopedia.com/terms/m/mezzaninefinancing.asp. [Accessed 25 February 2021].

12. Maier, D., 2018, The Romanian national innovation performance in the EU context, International Journal of Advanced Engineering and Management Research, 36, pp. 123-131, ISSN: 2456-3676.

13. Maier D., Verjel, A., Bercovici A., \& Maier A, 2017. Innovation Management System - a Necessity for Business Performance, 29th International-Business-InformationManagement Association Conference, Vienna, Austria, May 03-04, 2017.

14. National Agency of Innovation, 2018, The Technological and Business Innovation Strategy 2018-2030, [Online], Available at: https://dre.pt/application/conteudo/ 114832287. [Accessed 25 February 2021].

15. OECD, 2007, Innovation and Growth, Rationale for an Innovation Strategy, [Online], Available at: https://www.oecd.org/sti/39374789.pdf. [Accessed 25 February 2021].

16. OECD, 2018, Researchers, [Online], Available at: https://data.oecd.org/rd/ researchers.htm. [Accessed 25 February 2021].

17. OECD, 2019, OECD Review of Higher Education, Research and Innovation: Portugal, OECD Publishing, Paris https://www.oecdilibrary.org/docserver/9789264308138-en.pdf?expires=1615141463\&id=id\&accname $=$ oid031827\&checksum $=103302963949 B 9 A B A 2 E D F E B 8 B B B 5 E 3 E D$

18. OECD, 2020, Main Science and Technology Indicators, Vol. 1, 2020, [Online], Available at: https://www.oecd-ilibrary.org/science-and-technology/businessenterprise-expenditure-on-r-d-berd-as-a-percentage-of-gdp_83b74c19-en. [Accessed 21 January 2021].

19. Romanian Government, 2014, Strategia națională de cercetare, dezvoltare şi inovare 2014 - 2020, [Online], Available at: https://www.edu.ro/sites/default/files/_fi\% C8\%99iere/Minister/2016/strategii/strategia-cdi-2020_-proiect-hg.pdf. [Accessed 22 February 2021].

20. Romanian Government, 2015, HOTĂRÂRE Nr. 583/2015 din 22 iulie 2015 pentru aprobarea Planului naţional de cercetare-dezvoltare şi inovare pentru perioada 2015 - 2020 (PNCDI III), published in the Official Monitor no. 594 from 6th August 2015, [Online], Available at: https://www.research.gov.ro/uploads/programe-nationale/pncdi-iii/hg-583-2015-cu-modificarile-si-completarile-ulterioare.pdf. [Accessed 22 February 2021]. 
21. Romanian Government, 2020, Memorandum, [Online], Available at: https://www.research.gov.ro/uploads/memorandum/memorandum-psf.pdf. [Accessed 22 February 2021].

22. Santos, D. \& Simões, M. J. 2014: Regional innovation systems in Portugal: a critical evaluation, Investigaciones Regionales, 28, pp. 37-56

23. Sousa M. J, Carla F. \& Vaz D., 2019, Innovation Public Policy: The Case of Portugal, Vol. 6, pp. 14.

24. The Portuguese Agency for SME and Innovation, 2020, Portugal 2020 Support Schemes, [Online], Available at: https://www.iapmei.pt/Paginas/Financial-supportGrants-PT2020-Framework.aspx. [Accessed 21 January 2021]. 